\title{
MAKNA PENYAJIAN GONDANG PADA PROSESI KEMATIAN MASYARAKAT BATAK TOBA DI KECAMATAN DOLOK MASIHUL PROVINSI SUMATERA UTARA
}

\author{
Tria Ocktarizka \\ Universitas Syiahkuala Banda Aceh \\ triaocktarizka93@gmail.com
}

\begin{abstract}
Abstrak
Penelitian ini bertujuan untuk mendeskripsikan prosesi kematian masyarakat Batak Toba di Kecamatan Dolok Masihul, dan makna penyajian musik gondang pada prosesi kematian masyarakat Batak Toba di Kecamatan Dolok Masihul. Penelitian ini merupakan penelitian kualitatif deskriptif. Pengumpulan data dilakukan dengan teknik observasi, wawancara, dan dokumentasi. Hasil penelitian menunjukkan bahwa gondang memiliki peranan penting sebagai iringan setiap upacara Suku Batak. Prosesi kematian saur matua (kematian yang diharapkan) menyajikan gondang dan tortor sesuai dengan tata aturan adat. Setiap jenis gondang yang didendangkan oleh pargonsi (pemain gondang) dalam prosesi kematian memiliki makna yang berbeda beda. Gondang mula-mula ini ditujukan untuk Tuhan. Gondang Mula-mula memiliki makna bahwa semula Dia (Tuhan) sudah ada, dan Dia (Tuhan) memulai ada. Gondang Somba dimaksudkan sebagai sembah syukur kepada Tuhan yang telah menciptakan dan memelihara hidup manusia. Gondang Mangaliat memiliki makna bahwa Tuhan senantiasa memberikan keselamatan, kebahagiaan dan kesejahteraan bagi keluarga yang ditinggalkan. Gondang Hasahatan memiliki makna bahwa segala pinta yang meliputi hidup sejahtera bahagia dan penuh rejeki didengar Tuhan.
\end{abstract}

Kata kunci: makna, penyajian gondang, kematian, batak toba

\begin{abstract}
This study aims to describe the procession of Batak Toba's death in Subdistrict of Dolok Masihul, and the meaning of serving music gondang on procession Batak Toba's death in subdistrict of Dolok Masihul. This study is using a qualitative approach with descriptive type. The data collection was done by using observation, interview, and documenttaion techinques. The results showed that gondang has an important role as an accompaniment in every ceremony performed by Batak tribe community. Saur Matua (the expected death) funeral procession presented gondang and tortor based on the customary rules. Every kind of gondang which sang by pargonsi (gondang's player) in funeral procession has the meaning all it is own. Gondang mula-mula is presented for God. Gondang mula-mula originally means that since the very beginning Him (God) is already there. Gondang Somba means as a praise to worship God who created and maintain human life. Gondang
\end{abstract}


Tria Ocktarizka, Makna Penyajian Gondang pada Prosesi Kematian ...

Mangaliat has a meaning that God is always giving a salvation, joy and prosperity for the family remained. Gondang Hasatan means that every request including the prosperity life and full of fortune which listened by God.

Keywords: meaning, presentation of gondang, death, batak toba

\section{Pendahuluan}

Suku Batak adalah suku yang berasal dari Sumatera Utara. Dalam berbagai adegan kehidupan, orang Batak sangat mengacu pada sendi-sendi adat dan budaya yang ditanamkan sejak dari kecil di kampung halaman. Tidak hanya peristiwa-peristiwa indah atau sukacita, semisal acara perkawinan, kelahiran anak pertama, dan memasuki rumah baru, suku Batak juga mengedepankan adat dalam acara duka cita, yaitu kematian. Hal ini sudah berlaku turun-temurun sejak awal eksisnya suku Batak.

Kesenian daerah atau tradisional sangatlah berharga keberadaannya, karena dengan adanya kesenian daerah ini dapat menggambarkan corak kepribadian suku bangsa tersebut. Kesenian tradisional tersebut penting untuk dikaji karena melalui kajian itu dapat menggambarkan pandangan hidup dan aspek kepercayaan kelompok-kelompok masyarakat setempat. Rumahuru (2012: 2), mengatakan bahwa mengkaji kesenian tradisional tidak dapat dilepas-pisahkan dari dua unsur kehidupan kelompok-kelompok masyarakat setempat, yaitu upacara tradisional dan seni tradisional mereka.

Salah satu adat budaya masyarakat Batak Toba di Kecamatan Dolok Masihul yang masih digunakan yaitu musik tradisional gondang. Musik gondang ini selalu digunakan ketika masyarakat Batak Toba di Kecamatan Dolok Masihul melaksanakan rangkaian upacara adat istiadat mereka. Memainkan musik gondang tersebut tidak hanya dilakukan pada acara pesta perkawinan, dan acara-acara lainnya yang bersifat menghibur, namun permainan margondang juga dilakukan pada acara kematian yang diharapkan (mate saur matua).

Sinaga (2013: 21) mengatakan bahwa "prosesi atau upacara kematian adalah suatu rangkaian adat yang dilaksanakan oleh keluarga dalam memperlakukan jenazah Almarhum/Almarhumah. Prosesi atau upacara kematian dalam tradisi suku Batak Toba tergantung pada klasifikasi orang yang meninggal”. Sinaga (2013: 35) juga mengatakan bahwa "di adat Dalihan Natolu, orang meninggal disebut mate. Ada beberapa macam sebutan untuk orang yang meninggal diantaranya: mate ponggol, mate mangkar, mate sarimatua, mate saur matua, dan lain-lain”. Prosesi kematian yang dilakukan masyarakat Batak Toba memiliki persiapan yang sangat matang. Sinaga (2013: 92) mengatakan: "Prosesi kematian yang dilakukan untuk mate saur matua terdiri dari beberapa tahapan upacara dengan persiapan yang telah matang. Persiapan yang dimaksud diantaranya pembentukan panitia upacara kematian, persiapan untuk jenazah mulai dari pakaian hingga peti jenazah, dan susunan acara yang telah menjadi ketentuan dalam adat. Prosesi kematian mate saur matua terdiri dari dua bagian, yaitu upacara di dalam rumah dan halaman rumah duka.” 
Jadi dapat disimpulkan bahwa prosesi kematian adalah rangkaian upacara kematian yang dilakukan oleh keluarga dalam memperlakukan jenazah tergantung pada aturan yang terdapat dalam adat mereka.

Sinaga (2013: 36) mengatakan bahwa "Saur matua adalah orang yang meninggal dunia telah beranak cucu baik dari anak laki-laki maupun anak perempuan. Saur artinya lengkap atau sempurna dalam kekerabatan karena telah beranak cucu. Almarhum atau almarhumah yang telah meninggal itu sudah sempurna dalam kekerabatan, sehingga mate saur matua bukan menunjukkan kesedihan dari keturunannya, akan tetapi upacara yang dilakukan untuk menyatakan kegembiraan (suka cita) dari keturunannya”.

Pelaksanakan upacara merupakan penghormatan terakhir kepada yang meninggal Saur Matua tersebut, dilaksanakan suatu upacara adat yang besar dan melibatkan kehadiran gondang Batak Toba, setelah melalui musyawarah keluarga. Munthe (2015: 64) mengatakan bahwa "suku batak yang mulanya mempercayai adanya kekuatan roh nenek moyang, meyakini bahwa dengan menggunakan beragam bunyi-bunyian untuk memudahkan mereka memanggil roh nenek moyang yang dianutnya”.

Berdasarkan wawancara awal pada tanggal 20 Februari 2015, Silaban mengatakan bahwa "keluarga yang ekonominya mampu, melaksanakan upacara adat bisa sampai tujuh hari tujuh malam. Selama itu pula, para kerabat/keturunan yang meninggal itu memberikan penghormatan terakhir dengan cara manortor (menari) diiringi oleh Gondang, dengan kata lain selama acara adat itu digelar yaitu pada saat Mangondasi (marnortor sambil mengelilingi jenazah), selama itu pula suara gondang terus bergema”.

\section{Metode Penelitian}

\section{A. Pendekatan dan Jenis Penelitian}

Penelitian ini menggunakan pendekatan kualitatif dan menggunakan jenis deskriptif. Sanjaya (2013:59) mengatakan metode deskriptif adalah "penelitian yang dilakukan untuk menggambar atau menjelaskan secara sistematis, faktual, dan akurat mengenai fakta dan sifat populasi tertentu”. Penelitian deskriptif diartikan sebagai prosedur pemecahan masalah dengan menggambarkan atau melukiskan keadaan objek penelitian sekarang berdasarkan fakta-fakta yang tampak atau sebagaimana adanya.

\section{B. Lokasi Penelitian dan Sumber Data}

Lokasi penelitian ini dilaksanakan di Kecamatan Dolok Masihul Kabupaten Serdang Bedagai yang berjarak sekitar 80 km atau 2 jam perjalanan dari Pusat Kota Medan.

Informasi diperoleh dari informan yaitu beberapa ahli adat yang dipandang relevan dengan pemecahan masalah. Data dan informasi yang dikumpulkan selama penelitian digali dari beberapa sumber, yaitu:

1. St. Silaban (ketua adat suku Batak Toba di Kec.Dolok Masihul)

2. Sri Handayani Silaban (salah satu masyarakat yang paham akan prosesi kematian Batak Toba). 
Tria Ocktarizka, Makna Penyajian Gondang pada Prosesi Kematian ...

3. J. Simanjuntak (pemilik gondang di Kecamatan Dolok Masihul Kabupaten Serdang Bedagai).

\section{Teknik Pengumpulan Data}

1. Observasi

Menurut Arikunto (2009: 229) menyatakan bahwa "observasi adalah metode atau cara menganalisis secara sistematis mengenai tingkah laku dengan melihat dan mengamati individu atau kelompok secara langsung”. Observasi dilakukan saat penyajian musik gondang pada prosesi kematian, dengan memperhatikan tahapan-tahapan penyajian gondang dalam prosesi kematian masyarakat Batak. Instrumen yang digunakan saat melakukan observasi adalah pedoman observasi, buku catatan yang berfungsi untuk mencatat semua hal-hal yang berkaitan dengan penyajian musik gondang pada prosesi kematian.

\section{Wawancara}

Dalam penelitian ini dilakukan wawancara tidak berstruktur, yaitu wawancara yang bebas tidak menggunakan pedoman wawancara yang telah tersusun secara sistematis dan lengkap pengumpulan datanya.

\section{Dokumentasi}

Menurut Arikunto (2009: 236) “yang dimaksud dokumentasi adalah mencari data yang mengenai hal-hal atau variabel yang berupa catatan, transkrip, buku, surat kabar, majalah, agenda dan sebagainya”. Data yang berkaitan dengan penelitian ini berupa video dokumenter yang dimiliki oleh salah satu keluarga suku Batak Toba yang telah berdomisili di Kecamatan Dolok Masihul. Video tersebut dapat dijadikan referensi dan sebagai bahan penjelasan tentang penyajian musik gondang pada prosesi kematian masyarakat Batak Toba.

\section{Teknik Analisis Data}

Pada penelitian ini peneliti menggunakan tiga komponen analisis data yaitu reduksi data, penyajian data, dan verifikasi data.

\section{Hasil Penelitian dan Pembahasan}

\section{A. Prosesi Kematian Masyarakat Batak Toba di Kecamatan Dolok Masihul}

Upacara kematian pada masyarakat Batak Toba merupakan pengakuan bahwa masih ada kehidupan lain di luar kehidupan dunia. Tujuan masyarakat Batak Toba untuk mengadakan upacara kematian berdasarkan kepercayaan tentang kehidupan. Pada umumnya kematian saur matua-lah yang diselenggarakan upacara kematian.

Saur matua adalah orang yang meninggal dunia telah beranak cucu baik dari anak laki-laki maupun anak perempuan. Saur artinya lengkap/sempurna dalam kekerabatan, telah beranak cucu, karena yang telah meninggal itu adalah sempurna dalam 
kekerabatan maka harus dilaksanakan upacara dengan sempurna. Acara kematian yang diadakan oleh pihak keluarga tersebut dilaksanakan oleh pihak boru, karena dalam Dalihan Na Tolu, boru adalah pihak pelayan yang memegang peranan penting untuk kelancaran acara.

Pelaksanaan suatu upacara harus melalui fase-fase (tahapan-tahapan) yang harus dilalui oleh setiap yang melaksanakannya. Adapun tahapan-tahapan yang harus dilalui adalah sebagai berikut yaitu persiapan sebelum upacara dimulai serta pelaksanaan upacara kematian yang terdiri dari upacara di jabu (dalam rumah) dan upacara maralaman (halaman rumah).

\section{a. Persiapan Sebelum Upacara Dimulai}

Dalam kehidupan ini, setiap manusia dalam suatu kebudayaan selalu berkeinginan dan berharap dapat menikmati isi dunia ini dalam jangka waktu yang lama. Tetapi usaha untuk mencapai keinginan tersebut di luar jangkauan manusia, karena keterbatasan, kemampuan dan akal pikiran yang dimiliki oleh manusia. Selain itu, setiap manusia juga sudah mempunyai jalan kehidupannya masing-masing yang telah ditentukan batas akhir kehidupannya.

Batas akhir kehidupan manusia (mati) dapat terjadi dikarenakan berbagai hal, misalnya karena penyakit yang diderita dan tidak dapat disembuhkan lagi, kecelakaan dan sebab-sebab lain yang tidak dapat diketahui secara pasti.

Mengadakan upacara adat harus difikirkan matang-matang perlengkapan yang dibutuhkan untuk terselenggaranya upacara adat tersebut. Pihak keluarga, hula-hula dan boru terlebih dahulu bermusyawarah bagaimana rangkaian acara yang akan diadakan. Persiapan sebelum upacara diantaranya: mempersiapkan peti mati, mempersiapkan salib, menyediakan konsumsi untuk kerabat maupun pelayat, dan membicarakan perihal penyewaan musik gondang untuk upacara tersebut.

Lama atau tidaknya jenazah segera dimakamkan tergantung keputusan dari pihak keluarga besar, hula-hula dan kesepakatan keluarga inti. Apabila ada anggota keluarga seperti anak-anak almarhum/almarhumah yang belum melihat kondisi jenazah, dan sang anak meminta kesempatan untuk ditunggu maka pihak boru akan memakamkan jenazah setelah anggota keluarga lengkap hadir meskipun seminggu lamanya. Rangkaian acara pada prosesi kematian tepat dihari almarhum/almarhumah akan dimakamkan telah disusun oleh pihak boru. Para kerabat maupun tetangga datang ke acara tersebut dengan membawa parbue pir yaitu anyaman tikar yang dibentuk seperti karung dan berisi padi, untuk lebih jelasnya bentuk parbue pir dapat dilihat pada gambar berikut: 


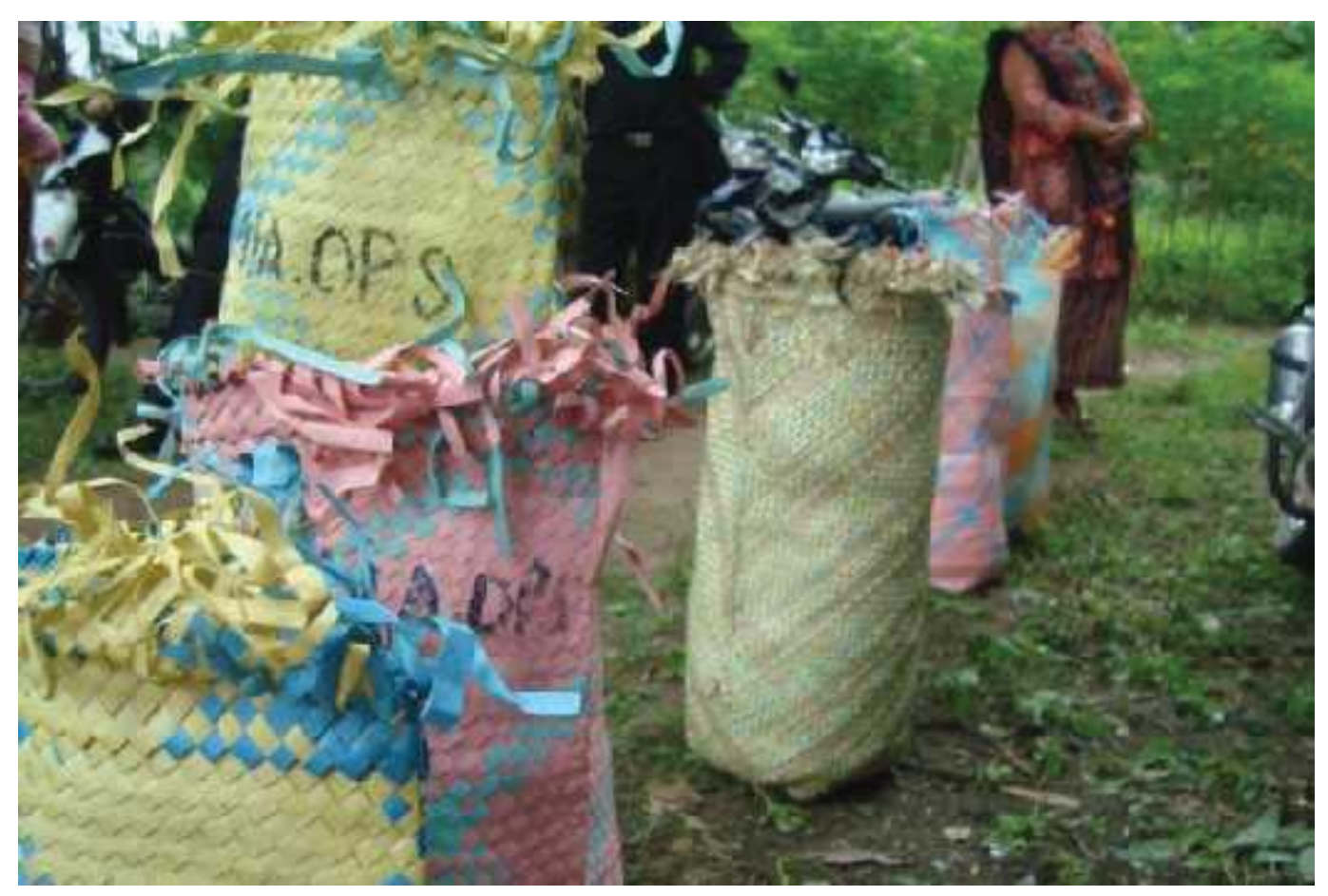

Gambar: Parbue Pir

Foto: Tria Ocktarizka, (2015)

Berdasarkan hasil wawancara tanggal 20 April 2015, Sri selaku narasumber mengatakan bahwa apabila yang meninggal tersebut sudah tua dan memiliki cucu maka isi dari parbue pir adalah padi sedangkan parbue pir yang diisi dengan beras diberikan untuk yang belum bercucu. Makna diberikannya padi kepada pihak keluarga menandakan bahwa padi tersebut adalah bantuan dari pihak kerabat dan tetangga yang dapat digunakan kedepannya sebagai simpanan pangan.

\section{b. Pelaksanaan Upacara Kematian Saur Matua}

Setelah keperluan upacara selesai dipersiapkan barulah upacara kematian saur matua ini dapat dimulai. Pelaksanaan upacara kematian saur matua ini terbagi atas dua bagian yaitu:

\section{Upacara Di Jabu (Di Dalam Rumah)}

Upacara di jabu ini biasanya di buka pada pagi hari (sekitar jam 10.00 WIB) oleh pengurus gereja, seperti upacara kematian yang dilaksanakan pada tanggal 25 April 2015 di Kecamatan Dolok Masihul. Masing-masing unsur Dalihan Na Tolu mengadakan acara penyampaian kata-kata penghiburan kepada keluarga. Ketika acara penyampaian katakata penghiburan oleh unsur-unsur Dalihan Na Tolu sedang berlangsung, diantara keturunan orangtua yang meninggal masih ada yang menangis.

Pada saat yang bersamaan, datanglah pargonsi (pemusik) sesuai dengan undangan yang disampaikan pihak keluarga kepada mereka. Tempat untuk pargonsi sudah dipersiapkan lebih dahulu yaitu di bagian teras rumah, lalu keluarga menjamu para pargonsi dengan memberikan makanan. Setelah acara makan bersama para pargonsi pun 
mengambil tempat mereka yang ada di teras rumah dan mempersiapkan instrumeninstrumen mereka masing-masing. Umumnya semua pemain duduk menghadap kepada yang meninggal, untuk lebih jelasnya dapat dilihat pada gambar berikut:

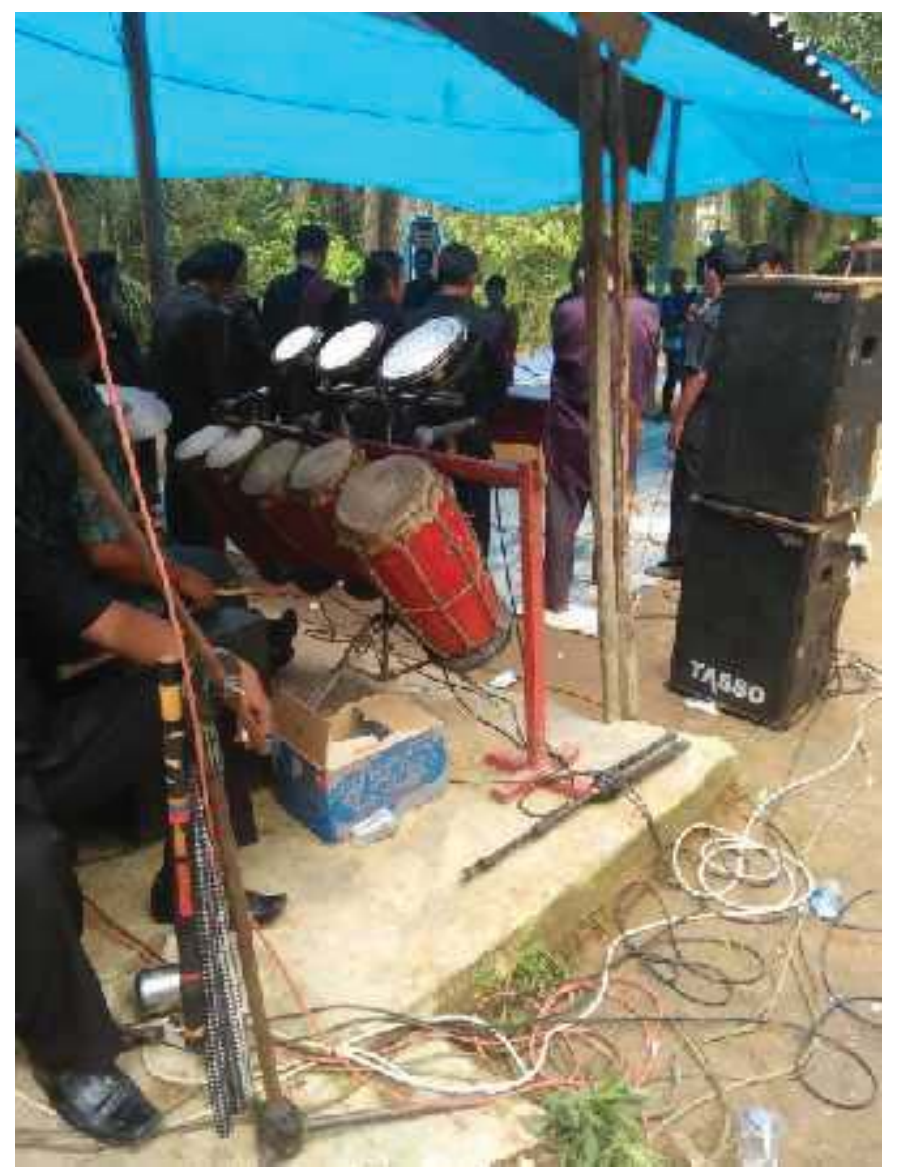

Gambar: Posisi Pargonsi

Foto: Tria Ocktarizka, (2015)

\section{Upacara Maralaman (Di Halaman Rumah)}

Ketika jenazah dibawa keluar oleh pihak keluarga, kemudian diaturlah posisi masing-masing unsur Dalihan Na Tolu. Sebelum menempati posisi masing-masing para keluarga dan hula-hula sesuai dengan unsur Dalihan Na Tolu, mereka manortor mengelilingi jenazah dan diakhiri dengan menempati posisi mereka. Pihak keluarga berdiri di sebelah kanan yang meninggal, hula-hula di sebelah kiri yang meninggal dan boru berdiri di depan yang meninggal. Jika masih ada suami atau isteri yang meninggal maka dia berdiri atau duduk di tempat yang searah dengan kepala jenazah, berikut adalah gambar untuk memperjelas uraian. 


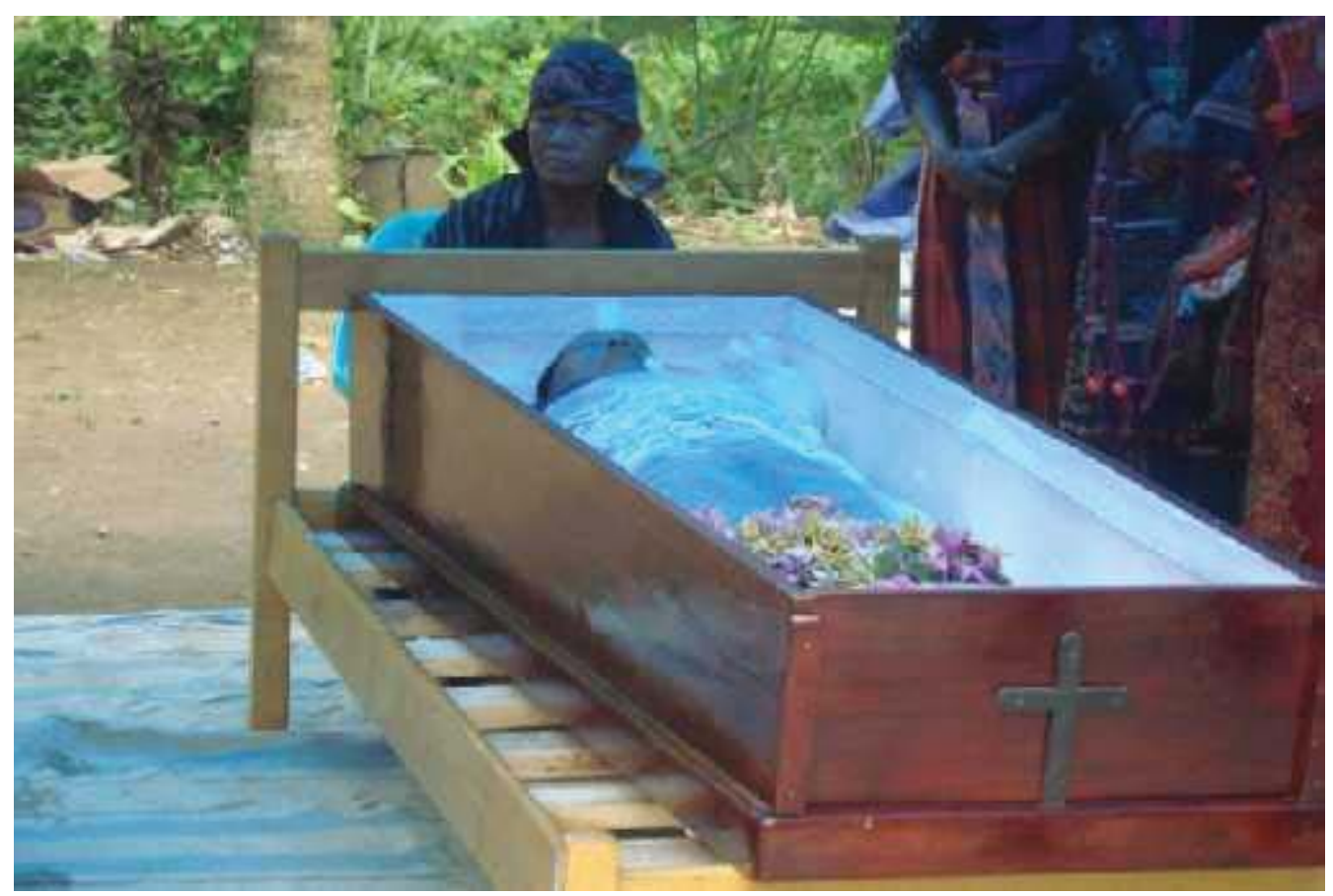

Gambar: Jenazah beserta istri

Foto: Tria Ocktarizka, (2015)

Kemudian kegiatan margondang dibuka oleh pengurus gereja (pangulani huria). Semua unsur Dalihan Na Tolu berdiri di tempatnya masing-masing. Pengurus gereja berkata kepada pargonsi agar dimainkan gondang. Tata acara yang dilaksanakan pada prosesi kematian teratur dan bertahap. Dimulai dari menyampaikan pesan-pesan dari pihak keluarga, pembacaan riwayat hidup almarhum/almarhumah oleh pihak hula-hula, manortor diiringi oleh gondang, dan ditutup dengan doa oleh pendeta sebelum jenazah dibawa ke pemakaman. Acara margondang dan manortor terdiri dari beberapa macam, diantaranya:

- Gondang Mula-mula

Sebelum manortor gondang pertama, perwakilan boru menyampaikan beberapa pesan-pesan untuk keluarga, lalu berkatalah boru tersebut kepada pargonsi atau pemusik gondang untuk memainkan musiknya. Gondang mula-mula adalah gondang pembukaan yang dimainkan oleh pargonsi. Gondang ini dimainkan untuk mengiringi manortor pihak keluarga dan kerabat.

Para keluarga manortor dengan menangkupkan kedua telapak tangan searah wajah atau dagu seperti memberi penghormatan sambil menggerakkan kedua lengan sesuai ritmis gondang yang dimainkan. Gondang ini hanya dimainkan kurang lebih 30 (tiga puluh) detik. Gondang ini dianggap juga sebagai gondang meminta restu kepada Tuhan untuk melaksanakan acara. Untuk lebih jelasnya dapat dilihat pada gambar berikut. 


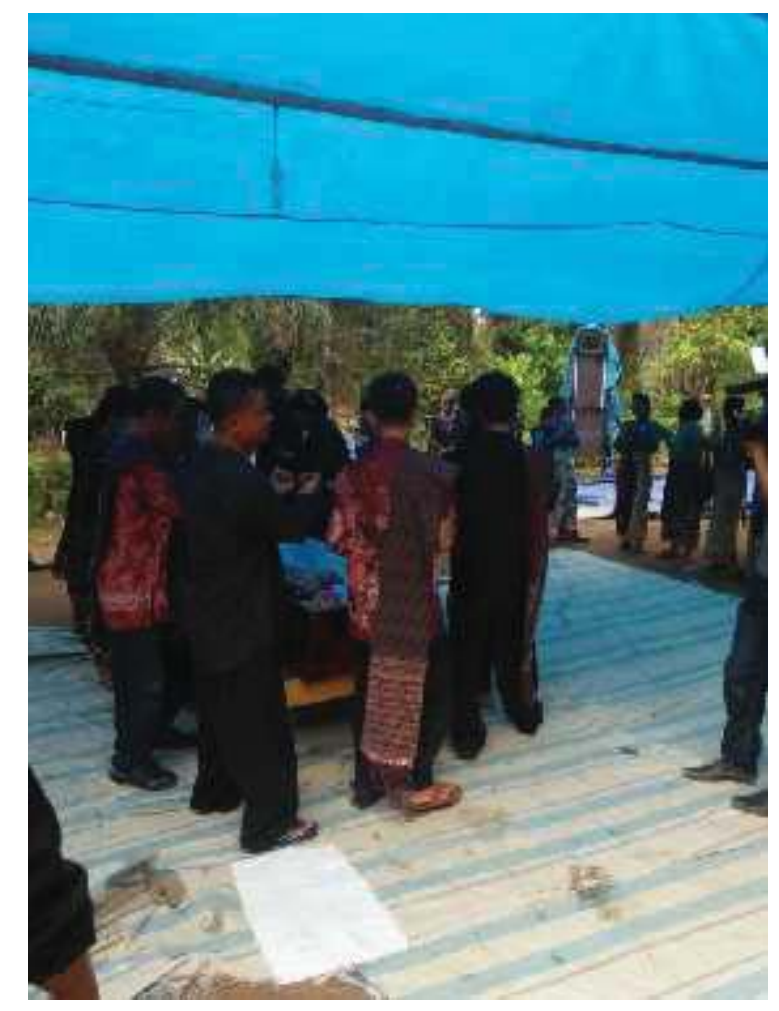

Gambar: Keluarga saat manortor

Foto: Tria Ocktarizka, (2015)

Pemusik gondang masing-masing berada di alat musiknya, posisi mereka sesuai dengan cara memainkan alat musik tersebut. Penabuh taganing dan pemain keyboard dalam posisi duduk sedangkan peniup sulim dalam posisi berdiri.

- Gondang Somba

Sama seperti gondang mula-mula, gondang somba juga dimainkan ketika pihak suhut (keluarga) dan hula-hula memberikan aba-aba kepada pargonsi untuk memainkannya. Gondang somba adalah gondang kedua dalam tahap penyajian gondang pada prosesi kematian saur matua masyarakat batak toba. Gondang somba dimainkan oleh pargonsi untuk mengiringi suhut dan boru manortor mengelilingi hula-hula. Kedua tangan para suhut dan boru masih ditangkup sambil menarikannya dengan melangkah seperti menghormati hula-hula.

Setelah manortor menghormati hula-hula, gondang berhenti sejenak sesuai perintah pemandu acara. Para pemandu acara menyampaikan kembali rangkaian adat yang akan dilakukan, lalu diperintahkannya lagi para pargonsi untuk melanjutkan gondang. Gondang lanjutan yang dimainkan pargonsi mengiringi para hula-hula untuk manortor sembari meletakkan ulos ke bahu suhut dan boru, untuk lebih jelasnya dapat dilihat pada gambar berikut. 


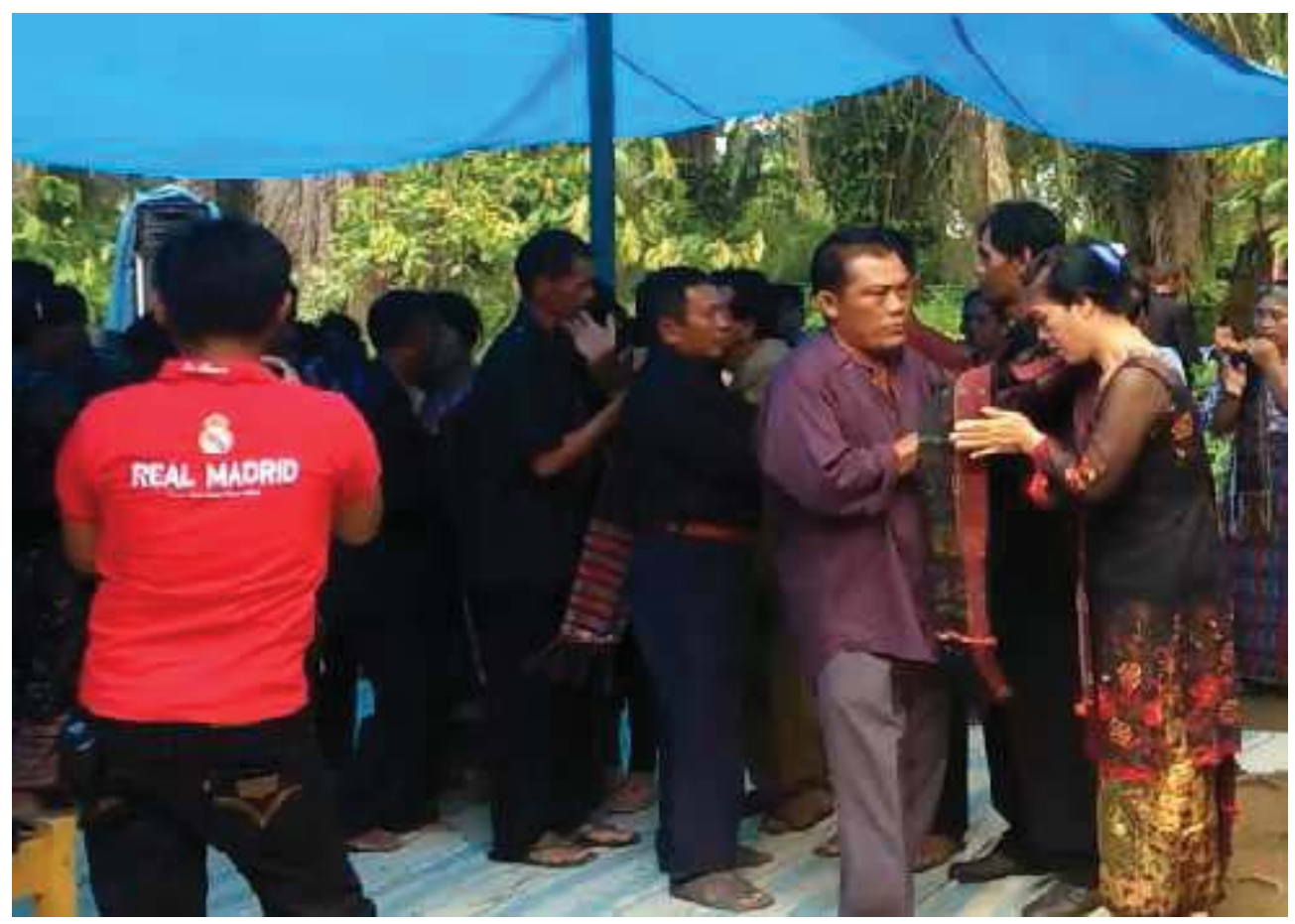

Gambar: hula-hula meletakkan ulos di bahu suhut dan boru

Foto: Tria Ocktarizka, (2015)

- Gondang Mangaliat

Gondang selanjutnya adalah gondang mangaliat atau istilah lainnya yaitu gondang liat-liat. Gondang mangaliat tersebut merupakan gondang terlama dalam rangkaian penyajian gondang pada prosesi kematian karena banyak terdapat aturan adat yang harus dipenuhi. Ketika pemimpin upacara berkata gondang mangaliat, maka menarilah dongan sabutuha (saudara se-marga) dengan memberikan parbue pir kepada suhut. Suhut menyambut kedatangan dongan sabutuha dengan gerakan manortor mundur.

Selain memberikan beras atau liang, disaat penyajian gondang mangaliat mereka juga memberikan ulos kepada semua keturunan orangtua yang meninggal (baik anak lakilaki dan anak perempuan). Biasanya setelah keturunan yang meninggal ini menerima ulos yang diberikan dongan sabutuha (saudara se-marga), lalu mereka mengelilingi peti jenazah. Anggota keluarga yang diselimuti dengan ulos seperti ditarik oleh pihak dongan sabutuha sambil manortor, tujuannya untuk mengisyaratkan bahwa masih ada saudara semarga yang ikut membantu keluarga yang ditinggalkan. Untuk lebih jelasnya dapat dilihat pada gambar berikut. 


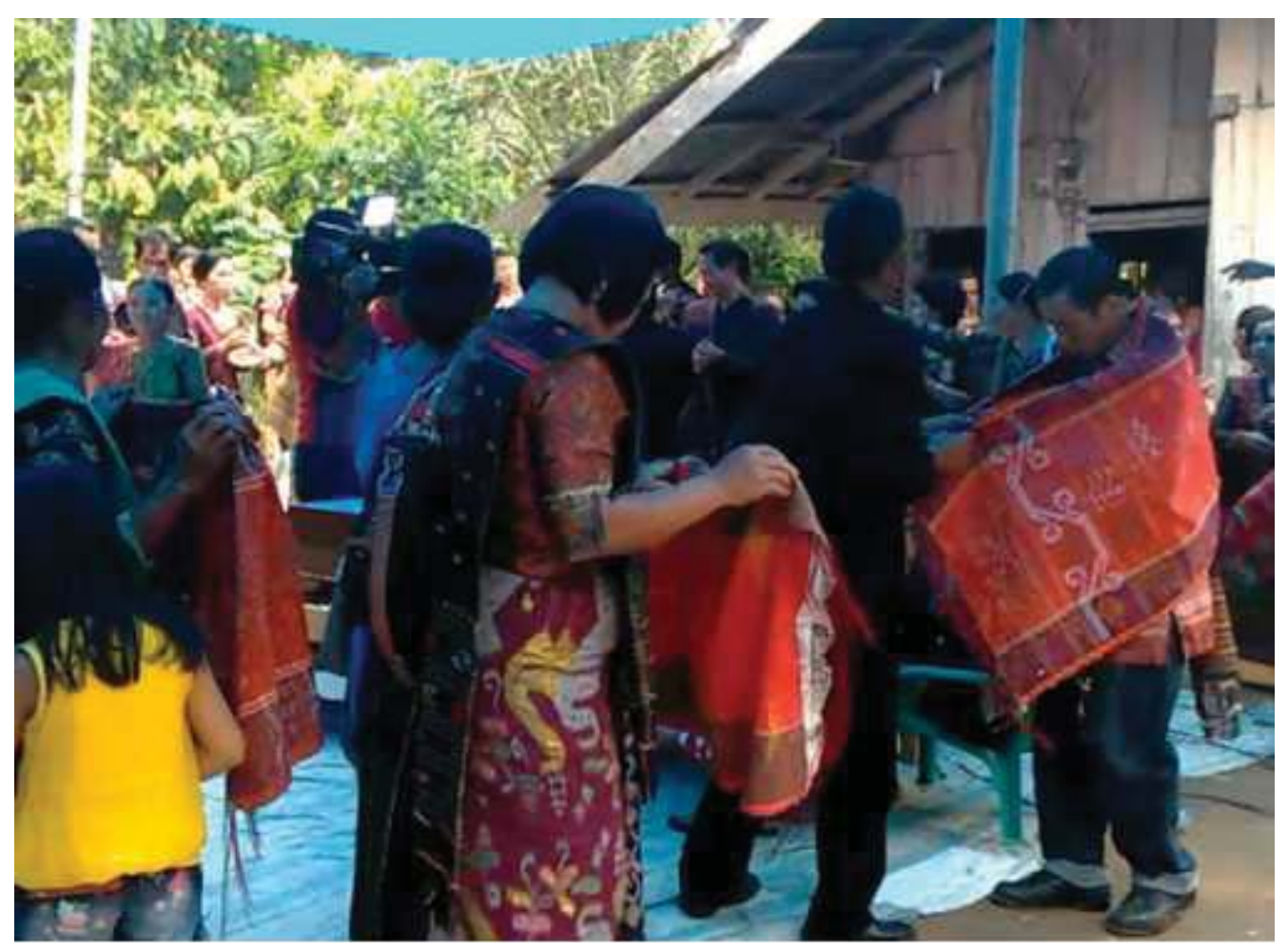

Gambar: Pemberian Ulos untuk keluarga

Foto: Tria Ocktarizka, (2015)

Pada saat penyajian gondang mangaliat, para pargonsi masih di posisinya

semula. Pargonsi masih berada di tempat yang telah ditentukan oleh pihak keluarga yaitu di teras rumah duka dengan posisi tubuh menghadap peti jenazah.

- Gondang Hasahatan

Gondang hasahatan adalah gondang penutup dari semua gondang yang telah disajikan. Semua yang manortor memegang ujung ulos dengan kedua tangan, dan ketika gondang hasahatan terdengar maka semua penari melambaikan ulos ke atas sembari meneriakkan kata "HORAS" sebanyak tiga kali. Posisi pemusik gondang juga masih berada di alat musiknya masing-masing meskipun sudah melewati beberapa tahapan penyajian gondang.

\section{B. Makna Penyajian Gondang pada Prosesi Kematian}

Setiap penampilan dalam upacara memiliki makna dan tujuan penyajiannya. Makna tersebut dimaksudkan untuk menyampaikan hal-hal yang berkaitan dengan upacara atau sebuah acara. Penyajian gondang pada prosesi kematian merupakan kebutuhan khusus bagi masyarakat Batak Toba. Musik gondang tersebut memiliki peranan yang sangat penting untuk kelancaran sebuah acara. Musik gondang menjadi musik pengiring tor-tor, karena tor-tor dan gondang merupakan kesatuan yang tidak bisa dipisahkan. Arti tor-tor dalam bahasa batak berarti tarian, tetapi bentuk tarian disini adalah tarian khas batak. Tortor ini termasuk bagian penting dalam upacara adat terutama upacara yang menggunakan persembahan gondang. 
Tria Ocktarizka, Makna Penyajian Gondang pada Prosesi Kematian ...

Setiap upacara adat menganggap gendang atau gondang yang berfungsi sebagai perantara untuk menyampaikan niat dan suara hati kepada Tuhan. Dari musik pengiring gerak tortor itu akan tergambar bagaimana suasana hati seseorang. Makna gondang tersebut juga tersirat dari penyampaian pihak keluarga di awal penyajian, sehingga ketika mendengar alunan gondang seolah pendengar dapat merasakan makna yang dimaksud dalam nada-nada yang dimainkan pemusik. Jika keadaan jiwanya penuh dengan kesusahan, jelas akan nampak dalam suasana musik dan gerakan tortor itu kurang bergairah begitu pula sebaliknya.

Dalam prosesi kematian masyarakat suku batak toba, gondang dan tortor terus disajikan sesuai dengan tata aturan adat. Setiap jenis gondang yang didendangkan oleh pargonsi memiliki maknanya tersendiri. Berikut adalah tahapan penampilan gondang pada prosesi kematian beserta maknanya:

1. Gondang Mula-mula

Gondang mula-mula adalah gondang yang dimainkan pertama sekali setelah jenazah dibawa keluar rumah dan diletakkan di halaman rumah oleh pihak boru dan keluarga. Gondang mula-mula disebut juga dengan istilah gondang pembuka atau permulaan. Gondang mula-mula dimainkan oleh pemusik setelah mendengar aba-aba dari pihak boru. Gondang mula-mula ini dimainkan dengan tempo agak cepat atau istilah musiknya disebut allegretto.

Gondang mula-mula ini ditujukan untuk Tuhan. Gondang Mula-mula memiliki makna bahwa semula Dia (Tuhan) sudah ada, dan Dia (Tuhan) memulai ada. Ada dunia, jagad raya beserta isinya, ada bumi dengan manusia bersama mahluk pendampingnya. Dia mula jadi, mula tempah, mula dari segala sesuatunya yang semuanya harus tunduk kepadaNya. Sehingga makna penyajian gondang mula-mula ini adalah untuk menggambarkan bahwa segala yang ada di dunia ini ada mulanya, baik itu manusia, kekayaan dan kehormatan.

\section{Gondang Somba}

Gondang somba adalah gondang urutan kedua yang disajikan pargonsi sesuai permintaan hula-hula dan suhut (keluarga). Penyajian gondang somba dimaksudkan sebagai sembah syukur kepada Tuhan yang telah menciptakan dan memelihara hidup manusia. Manusia yang diciptakan Tuhan ini saling bahu-membahu sesamanya, dan atas berkat Tuhan inilah segala kesedihan dapat dilupakan. Gondang somba memiliki makna sikap menyembah dan berterimakasih kepada Tuhan Sang Penyelenggara hidup manusia itu pantas disembah-sujudi karena dengan kehendakNya diciptakan manusia yang akan mengangkat kesedihan sesama manusia.

\section{Gondang Mangaliat}

Gondang mangaliat adalah gondang yang dimainkan setelah gondang somba. Gondang mangaliat memiliki makna bahwa Tuhan senantiasa memberikan keselamatan, kebahagiaan dan kesejahteraan bagi keluarga yang ditinggalkan oleh jenazah saur matua tersebut. Hal tersebut dapat dirasakan dari lantunan gondang yang lebih bersemangat dari gondang sebelumnya dan dapat dilihat dari gerak tangan pada manortor yang membuka kedua telapak tangan seperti meminta kesejahteraan di atas jenazah. Selanjutnya dari penyajian gondang mangaliat disaat penyambutan dongan sabutuha ini bermakna bahwa saudara-saudara se-marga dan saudara-saudara yang memenuhi unsur Dalihan Na Tolu 
senantiasa dapat dijadikan sandaran pertolongan disaat keluarga si almarhum/almarhumah kesusahan, sehingga roh almarhum/almarhumah dapat tenang tanpa memikirkan beban keluarganya.

\section{Gondang Hasahatan}

Gondang hasahatan adalah gondang penutup dari semua gondang. Gondang ini memiliki makna bahwa segala pinta yang meliputi hidup sejahtera bahagia dan penuh rejeki didengar Tuhan. Setelah selesai ditarikan rnereka semuanya mengucapkan "HORAS" sebanyak tiga kali. Hal tersebut semakin menunjukkan bahwa makna penyajian gondang hasahatan tersebut hanya sebagai penegas dari segala doa mereka.

\section{Kesimpulan}

Berdasarkan hasil penelitian mengenai makna penyajian musik gondang pada prosesi kematian masyarakat Batak Toba di Kecamatan Dolok Masihul Kabupaten Serdang Bedagai, dapat disimpulkan bahwa saur matua adalah sebutan masyarakat Batak Toba untuk jenazah yang sudah memiliki cucu dari semua anaknya. Acara kematian yang diadakan oleh pihak keluarga tersebut dilaksanakan oleh pihak boru, karena dalam Dalihan Na Tolu, boru adalah pihak pelayan yang memegang peranan penting untuk kelancaran acara.

Upacara kematian tersebut terbagi menjadi dua tahapan upacara di jabu (di dalam rumah) dan upacara maralaman (di halaman rumah). Tata acara yang dilaksanakan pada prosesi kematian teratur dan bertahap. Dalam prosesi kematian masyarakat batak toba ini terdiri dari beberapa macam gondang, diantaranya: Gondang Mula-mula, Gondang Somba, Gondang Mangaliat dan Gondang Hasahatan. Makna dari masing-masing gondang yang disajikan tersebut berbeda. Berikut adalah makna penyajian gondang tersebut:

a. Gondang mula-mula memiliki makna untuk menggambarkan bahwa segala yang ada di dunia ini ada mulanya, baik itu manusia, kekayaan dan kehormatan. Segala permulaan tersebut berasal dari Tuhan, oleh karena itu gondang mula-mula ditujukan untuk Tuhan.

b. Gondang Somba memiliki makna bahwa sikap menyembah dan berterimakasih kepada Tuhan Sang Penyelenggara hidup manusia itu pantas disembah-sujudi karena dengan kehendakNya diciptakan manusia yang akan mengangkat kesedihan sesama manusia.

c. Gondang mangaliat memiliki makna bahwa Tuhan senantiasa memberikan keselamatan, kebahagiaan dan kesejahteraan bagi keluarga yang ditinggalkan oleh jenazah saur matua tersebut. Hal tersebut dapat dirasakan dari lantunan gondang yang lebih bersemangat dari gondang sebelumnya dan dapat dilihat dari gerak tangan pada manortor yang membuka kedua telapak tangan seperti meminta kesejahteraan di atas jenazah. 
Tria Ocktarizka, Makna Penyajian Gondang pada Prosesi Kematian ...

d. Gondang hasahatan adalah gondang penutup dari semua gondang. Gondang ini memiliki makna bahwa segala pinta yang meliputi hidup sejahtera bahagia dan penuh rejeki didengar Tuhan.

\section{Kepustakaan}

Arikunto, Suharsimi. 2009. Prosedur Penelitian (Suatu Pendekatan Praktik). Jakarta: Rineka Cipta.

Munthe, Nurelide. 2015. Meretas Budaya Masyarakat Batak Toba dalam Cerita Sigalegale. Medan: CV Mitra.

Rumahuru, Yance Z. 2012. Kesenian Tradisional di Seram Bagian Barat. Ambon:

Balai Pelestarian Nilai Budaya Ambon.

Sanjaya, Wina. 2013. Penelitian Pendidikan. Jakarta: Kencana Prenada Media

Group.

Sinaga, Richard. 2013. Meninggal Adat Dalihan Natolu (Adat tu na Monding). Jakarta: Dian Utama dan Kerabat. 